\title{
GOVERNING BEHAVIOR
}





\title{
GOVERNING BEHAVIOR
}

\author{
How Nerve Cell Dictatorships and \\ Democracies Control Everything We Do
}

A R I B E R K O W I T Z

Harvard University Press

Cambridge, Massachusetts

London, England

2016 
Copyright (c) 2016 by the President and Fellows of Harvard College All rights reserved

Printed in the United States of America

First printing

Library of Congress Cataloging-in-Publication Data

Berkowitz, Ari, 1961- author.

Governing behavior : how nerve cell dictatorships and democracies control everything we do / Ari Berkowitz.

pages $\mathrm{cm}$

Includes bibliographical references and index.

ISBN 978-0-674-73690-0 (cloth : alk. paper)

1. Neurons. 2. Neural networks (Neurobiology) 3. Animal behavior.

I. Title.

QP363.3.B47 2016

612.8'1046-dc23 2015033365 


\section{In memory of \\ Paul Grobstein}

$\&$

JON I. (“JACK") ROBERTS 
